\title{
Buchner and Beyond: Arene Cyclopropanation as Applied to Natural Product Total Synthesis
}

\author{
Sarah E. Reisman, * Roger R. Nani, Sergiy Levin
}

The Warren and Katharine Schlinger Laboratory for Chemistry and Chemical Engineering, Division of Chemistry and Chemical Engineering, California Institute of Technology, Pasadena, California 91125, USA

Fax +1(626)3958436; E-mail: reisman@ caltech.edu

Received 25 April 2011

\begin{abstract}
Buchner and Curtius first reported the cyclopropanation of arenes in 1885. Since the initial discovery, the Buchner reaction has been the subject of significant research by both physical and synthetic organic chemists. Described herein is a brief overview of the Buchner reaction and related arene cyclopropanation processes, with an emphasis on their application to natural product total synthesis.
\end{abstract}

Key words: Buchner, cyclopropanation, diazo, norcaradiene, cycloheptatriene, total synthesis

Over the past century, the Buchner reaction ${ }^{1}$ has become an important method for the preparation of seven-membered rings. Although Buchner originally proposed that the thermolysis of ethyl diazoacetate (1) in benzene provided norcaradiene $\mathbf{2}$, Doering and co-workers, with the assistance of modern NMR techniques, subsequently characterized the products as a mixture of cycloheptatrienes 4-6 (Scheme 1). ${ }^{2,3}$ We now understand that cycloheptatriene $\mathbf{3}$ arises from reversible $6 \pi$ disrotatory electrocyclic ring opening of the initially formed norcaradiene $\mathbf{2}$, and that compounds $\mathbf{2}$ and $\mathbf{3}$ exist in a dynamic equilibrium that heavily favors $\mathbf{3}$. Under the thermal conditions, [1,5]-hydride migration results in isomerization of 3 to a thermodynamic mixture of cycloheptatrienes 4 6.

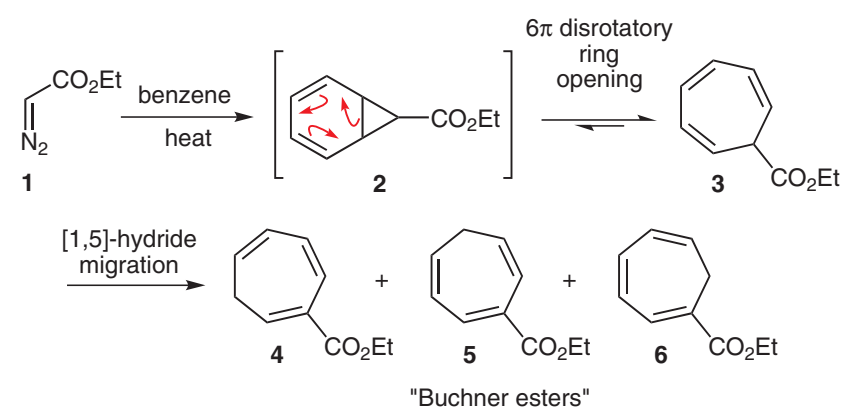

Scheme 1 The Buchner reaction

The original report by Buchner ${ }^{1}$ and subsequent findings by Doering ${ }^{2}$ have sparked volumes of research on the norcaradiene-cycloheptatriene equilibrium. ${ }^{4}$ In simple, unconstrained systems the equilibrium lies toward the

SYNLETT 2011, No. 17, pp 2437-2442

Advanced online publication: 06.10.2011

DOI: 10.1055/s-0031-1289520; Art ID: P01711ST

(c) Georg Thieme Verlag Stuttgart · New York

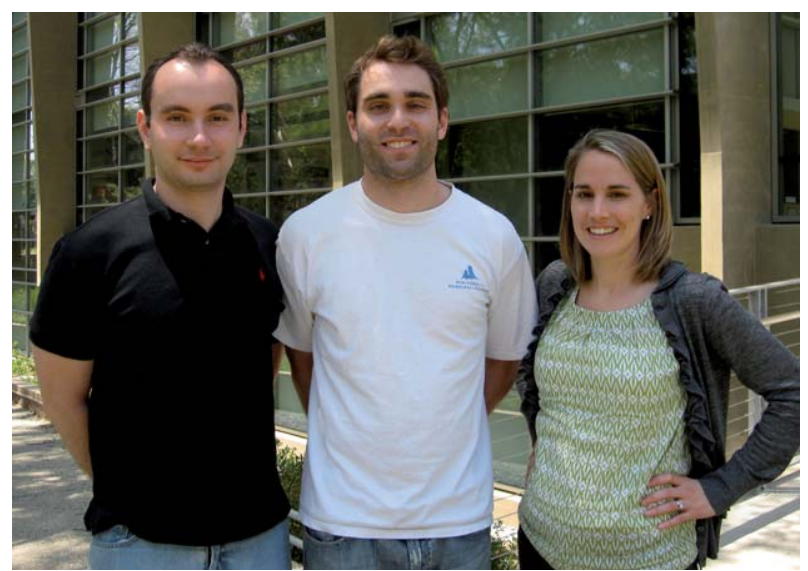

Roger Nani (center) was raised in the Bronx, New York, USA. He conducted his undergraduate studies at Boston College, and received his BSc degree in Biochemistry in 2006. He is currently a PhD student in Chemistry at the California Institute of Technology. Sergiy Levin (left) was born in Kharkov, Ukraine. He received his Diploma in Chemistry from Kharkov National University in Ukraine in 2002, and his $\mathrm{PhD}$ in Chemistry from the University of California, Irvine in 2008. From 2009-2011 he was a postdoctoral scholar at the California Institute of Technology. He is currently a postdoctoral scientist at Johnson \& Johnson in Spring House, PA. Sarah Reisman (right) was born and raised in Bar Harbor, Maine, USA. In 2001, she received her BA degree from Connecticut College, and in 2006, she earned her $\mathrm{PhD}$ in organic chemistry from Yale University. After two years as a postdoctoral fellow at Harvard University, Sarah joined the faculty at the California Institute of Technology in 2008 as an Assistant Professor of Chemistry. The overarching goal of the Reisman laboratory is to discover, develop, and study new chemical reactions within the context of natural product total synthesis.

cycloheptatriene species. ${ }^{5,6}$ However, several elegant studies have determined that a variety of steric $^{7}$ and electronic $^{8}$ factors may alter this equilibrium to instead favor the norcaradiene. For example, Vogel and co-workers prepared and compared the ${ }^{1} \mathrm{H}$ NMR spectra of two closely related compounds, 7 and $\mathbf{9}$ (Figure 1). ${ }^{9}$ Illustrating the influence of geometric constraints on the equilibrium, they found that for the ten-carbon system, norcaradiene 7 predominates; on the other hand, the analogous elevencarbon framework favors the ring-opened cycloheptatriene $\mathbf{1 0 .}$

Early synthetic applications of the thermal and photochemical Buchner reaction were plagued by poor yields and the formation of isomeric cycloheptatriene products that were difficult to separate. ${ }^{10}$ The synthetic utility of this transformation was greatly improved with the advent 


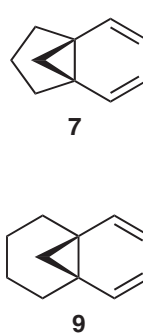

not observed

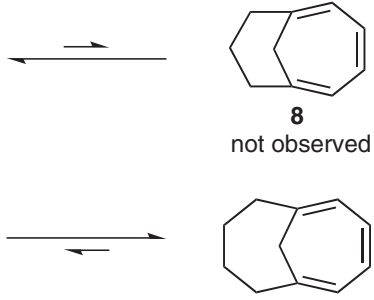

10

Figure 1 The norcaradiene-cycloheptatriene equilibrium can be perturbed by the geometric constraints of bridging systems.

of homogeneous transition metal catalysis. In 1973, Scott reported that $\mathrm{CuCl}$ catalyzes the intramolecular Buchner reaction of phenyldiazobutane 11 to give, following [1,5]hydride migration, cross-conjugated dihydroazulenone $\mathbf{1 2}$ (Scheme 2). ${ }^{11}$ Subsequently, Noels, Hubert, and co-workers reported that $\mathrm{Rh}_{2}(\mathrm{tfa})_{4}$ catalyzes the reaction between ethyl diazoacetate (1) and benzene (13) at room temperature to quantitatively yield cycloheptatriene $3{ }^{12}$ These results provided the framework for the application of arene cyclopropanation in natural product total synthesis.

(a)<smiles>N#CC(=O)CCc1ccccc1</smiles>

(b)<smiles>c1ccccc1</smiles>

13<smiles>CCOC(=O)C=[W]</smiles>

1
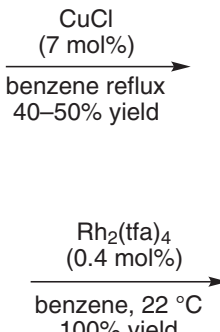

$100 \%$ yield
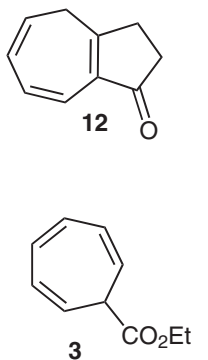

Scheme 2 (a) Scott reported the first $\mathrm{Cu}$-catalyzed intramolecular Buchner reaction in $1973 .^{11}$ (b) Noels, Hubert, and co-workers reported the first $\mathrm{Rh}$-catalyzed Buchner reaction in $1980 .{ }^{12}$

Following the early reports of copper and rhodium catalysis, ${ }^{13}$ a number of research groups have applied intramolecular variants of the Buchner reaction to the preparation of polycyclic systems containing seven-membered rings. ${ }^{14}$ The vast majority of studies reported to date have focused on compounds with two-carbon tethers between the $\alpha$-diazocarbonyl and the arene (e.g. 14a, Scheme 3); ${ }^{15}$ however, some heteroatom linkers have also been pursued. ${ }^{16}$ These studies have primarily utilized arenes bearing electron-releasing substituents, as electron-deficient arenes are typically poor substrates for arene cyclopropanation. ${ }^{14,17}$ The interest in aryldiazobutanone substrates such as $\mathbf{1 4 a}$ is fueled in part by the large number of sesquiterpene natural products with bicyclo[5.3.0]decane core structures (e.g. 20, Scheme 4), to which this synthetic methodology provides a convenient entry. ${ }^{14 \mathrm{~d}}$ Moreover, these substrates do not usually exhibit substantial levels of competing benzylic $\mathrm{C}-\mathrm{H}$ insertion; as a result, higher yields of the cycloheptatriene products (15a) are observed when compared to the Buchner reactions of the corresponding aryldiazopentane systems (e.g. 14b). As will be

discussed later, substrates with three-atom tethers are prone to cyclopentanone formation via $\mathrm{C}-\mathrm{H}$ insertion. ${ }^{18}$

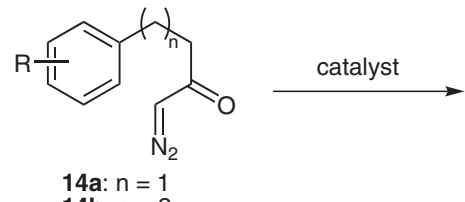<smiles>[R]C1=CC=CC2=C(C1)C(=O)CC2</smiles>

14b: $n=2$

15b: $n=2$

Scheme 3 Commonly studied intramolecular Buchner substrates

In an early demonstration of the utility of the Rh-catalyzed intramolecular Buchner reaction, McKervey and Kennedy reported that exposure of $\alpha$-diazo ketone 16 to catalytic $\mathrm{Rh}_{2}$ (mandelate) ${ }_{4}$ quantitatively provided a mixture of norcaradiene 17 and cycloheptatriene $18 .{ }^{19} \mathrm{Al}-$ though norcaradiene $\mathbf{1 7}$ was the major species observed by ${ }^{1} \mathrm{H}$ NMR spectroscopy, chemoselective reduction of the equilibrating mixture allowed for isolation of cycloheptatriene $\mathbf{1 9}$ in $77 \%$ yield as a mixture of diastereomers. Cycloheptatriene $\mathbf{1 9}$ was subsequently advanced in several steps to $( \pm)$-confertin A (20).
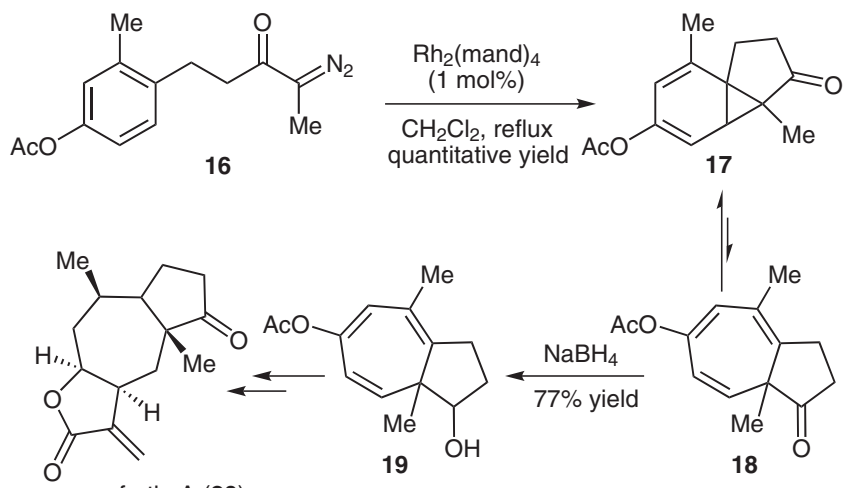

Scheme 4 McKervey and Kennedy utilized an intramolecular Buchner reaction of $\alpha$-diazo ketone $\mathbf{1 6}$ to prepare the bicyclo[5.3.0]decane core of $( \pm)$-confertin A (20). ${ }^{19}$

In their synthesis of hainanolidol (24), Mander and coworkers employed an intramolecular arene cyclopropanation reaction to access a 5,7-fused ring system in a considerably more complex setting (Scheme 5). ${ }^{20}$ Treatment of $\alpha$-diazo ketone 21 with catalytic $\mathrm{Rh}_{2}$ (mandelate) $)_{4}$ resulted in arene cyclopropanation followed by electrocyclic ring opening to give an unstable cycloheptatriene. Immediate exposure to DBU resulted in isomerization of the olefin to give the more stable and thermodynamically preferred enone 23. Tricycle $\mathbf{2 3}$ was advanced in seven steps to hainanolidol $(\mathbf{2 4}) .^{21}$

Although the yields of metal-catalyzed intramolecular Buchner reactions are highly sensitive to both the substrate and the catalyst, the following reactivity trends have emerged from the collective research of several laboratories: ${ }^{14}$ (1) rhodium catalysts promote Buchner reactions at lower temperatures than copper catalysts $;^{12}(2)$ in systems where $\mathrm{C}-\mathrm{H}$ insertion is disfavored, rhodium catalysts typically provide higher yields than copper catalysts, ${ }^{15}$ (3) for 


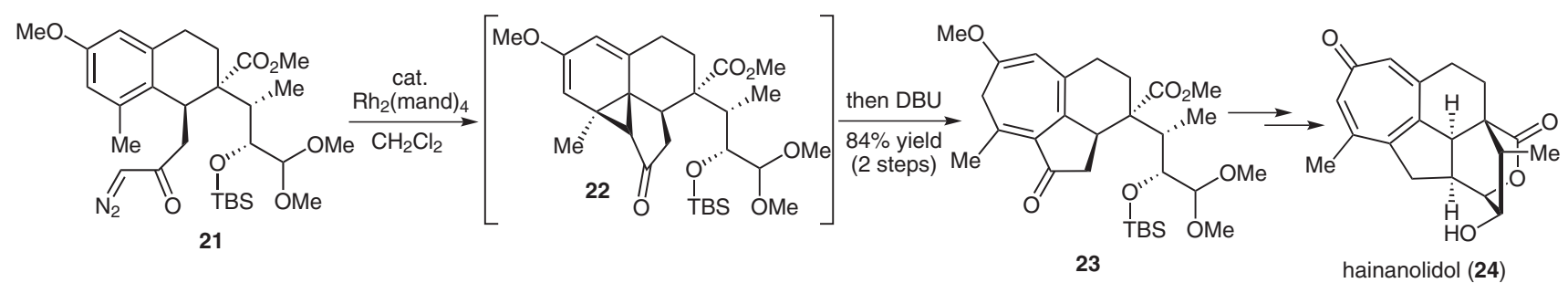

Scheme 5 Mander and co-workers employed an intramolecular Buchner reaction of a highly functionalized substrate in their synthesis of hainanolidol (24). ${ }^{20}$

rhodium catalysts, electron-deficient ligands favor arene cyclopropanation, whereas electron-rich ligands favor $\mathrm{C}-$ $\mathrm{H}$ insertion; ${ }^{17}$ (4) ortho-substituted aryldiazobutane substrates undergo arene cyclopropanation at the less substituted site ${ }^{15}(5)$ doubly stabilized diazo substrates (e.g. $\alpha$ diazo- $\beta$-keto esters) generally favor $\mathrm{C}-\mathrm{H}$ insertion over arene cyclopropanation. ${ }^{18}$

In contrast to the numerous studies targeting the formation of bicyclo[5.3.0]decanes by intramolecular arene cyclopropanation, there are far fewer examples of reactions that provide the corresponding bicyclo[5.4.0] undecanes. This is likely due to the increased propensity for metal-carbenoid insertion into the activated benzylic $\mathrm{C}-\mathrm{H}$ bonds of the corresponding substrates (e.g. 14b, Scheme 3). For aryldiazobutane substrates, the strain incurred during cyclobutanone formation disfavors $\mathrm{C}-\mathrm{H}$ insertion processes; alternatively, it is well known that $\mathrm{C}-\mathrm{H}$ insertion to give five-membered rings is highly favorable. ${ }^{22}$ The competition between $\mathrm{C}-\mathrm{H}$ insertion and arene cyclopropanation is clearly illustrated by Mander and co-workers' studies of tetralin 2-diazomethyl ketones (25, Table 1). ${ }^{23}$ Of note, due to the geometric constraints of these systems, the norcaradiene valence tautomer $\mathbf{2 6}$ is favored. These studies revealed that the yields of arene cyclopropanation are highly dependent on both the catalyst and the arene substitution pattern. In general, rhodium catalysts provided mixtures of norcaradiene $\mathbf{2 6}$ and cyclopentanone $\mathbf{2 7}$, sometimes favoring 27. Alternatively, copper catalysts provided lower overall yields, but delivered better selectivity for the norcaradiene (Table 1, entries 2, 4, 6).

Mander subsequently utilized this methodology as part of a cascade reaction sequence in an elegant total synthesis of gibberellin $\mathrm{GA}_{103}\left(\mathbf{3 1}\right.$, Scheme 6). ${ }^{24}$ Treatment of $\alpha$-diazo ketone 28 with $\mathrm{Cu}(\mathrm{acac})_{2}$ in refluxing dichloroethane provided unstable norcaradiene $\mathbf{2 9}$, which was trapped in situ by addition of 3-methylfuran-2,5-dione to deliver polycycle 30. This remarkable sequence proceeded in $75 \%$ yield over two steps. Polycycle 30 was subsequently elaborated in 12 steps to $\mathrm{GA}_{103}$.

In 2008, salvileucalin B (32, Scheme 7), an unusual cytotoxic diterpenoid natural product containing a norcaradiene core, was isolated from the plant Salvia leucantha. ${ }^{25}$ Intrigued by the fascinating structure, our research group initiated a total synthesis effort in which the central norcaradiene of $\mathbf{3 2}$ was envisioned to arise from an arene cyclopropanation reaction of an $\alpha$-diazocarbonyl of the

Table 1 Mander's Studies of Tetralin 2-Diazomethyl Ketones ${ }^{23}$

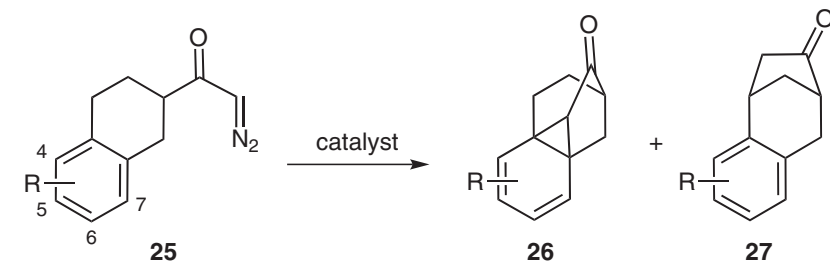

\begin{tabular}{ccccc}
\hline Entry & $\mathrm{R}$ & Catalyst & Yield of 26 (\%) & Yield of 27 (\%) \\
\hline 1 & $\mathrm{H}$ & $\mathrm{Rh}_{2}(\mathrm{OAc})_{4}$ & 39 & 41 \\
2 & $\mathrm{H}$ & $\mathrm{Cu}(\mathrm{acac})_{2}$ & 56 & 6 \\
3 & $5-\mathrm{MeO}$ & $\mathrm{Rh}_{2}(\mathrm{OAc})_{4}$ & 34 & 41 \\
4 & $5-\mathrm{MeO}$ & $\mathrm{Cu}(\mathrm{acac})_{2}$ & 56 & 12 \\
5 & $6-\mathrm{MeO}$ & $\mathrm{Rh}_{2}(\mathrm{OAc})_{4}$ & 71 & 14 \\
6 & $6-\mathrm{MeO}$ & $\mathrm{Cu}(\mathrm{acac})_{2}$ & 61 & 17 \\
7 & $7-\mathrm{MeO}$ & $\mathrm{Rh}_{2}(\mathrm{OAc})_{4}$ & 46 & 44 \\
8 & $7-\mathrm{MeO}$ & $\mathrm{Cu}(\mathrm{acac})_{2}$ & 64 & 3 \\
\hline
\end{tabular}<smiles>C=Cc1ccc(OC)c2c1CCC(C(=O)C=N)C2</smiles><smiles>COC1=CC=C(C=CC2CCCCC2)C23CCCCC12C3</smiles>

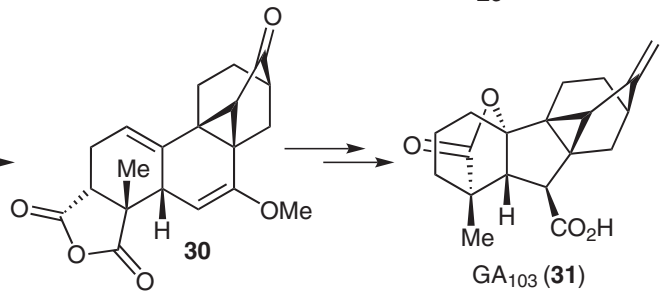

Scheme 6 An arene cyclopropanation-Diels-Alder cascade reaction in Mander's synthesis of $\mathrm{GA}_{103}(\mathbf{3 1})^{23}$

general structure 34. From the outset, we recognized that the fully substituted cyclopropane of salvileucalin B was a particularly challenging motif to access by arene cyclopropanation; indeed, despite years of research, there was no precedent for similar transformations. In addition, Mander's studies on the cyclopropanation of tetralin 2diazomethyl ketone derivatives clearly illustrated that in systems where five-membered ring formation is possible, 
$\mathrm{C}-\mathrm{H}$ insertion competes with arene cyclopropanation (see Table 1). Moreover, several studies have demonstrated that doubly stabilized diazo compounds (such as those we envisioned utilizing in the synthesis of 32) are exceptionally prone to $\mathrm{C}-\mathrm{H}$ insertion. ${ }^{18}$

In order to identify conditions to promote intramolecular arene cyclopropanation reactions of substrates related to salvileucalin B, model substrate 35a was prepared (Table 2). ${ }^{26}$ Consistent with Mander's findings, rhodium catalysts provided low yields of the desired norcaradiene 36a, instead favoring the formation of isomeric $\mathrm{C}-\mathrm{H}$ insertion products. ${ }^{27}$ On the other hand, copper catalysts gave improved yields of 36a, with $\mathrm{Cu}(\mathrm{tfacac})_{2}$ in refluxing dichloroethane providing the best results (Table 2, entry 5).

Although the formation of norcaradiene 36a was promising, it was considered critical to utilize an $\alpha$-diazocarbonyl substrate that provided direct access to a fully substituted cyclopropane product. Unfortunately, the use of $\alpha$-diazoethyl ketone $35 \mathbf{b}$ or $\alpha$-diazo- $\beta$-keto ester 35c in conjunction with a variety of either rhodium or copper catalysts provided only trace quantities of the corresponding norcaradiene products. ${ }^{28}$ Instead, the major products were a mixture of isomeric cyclopentanones resulting from $\mathrm{C}-\mathrm{H}$ insertion, even when copper catalysts were used. The significant drop in yield observed when switching from the $\alpha$-diazomethyl ketone to $\alpha$-diazoethyl ketone, which are similar in their electronic properties but differ in their steric profile, suggested that less sterically encumbered substrates may provide improved yields of norcaradiene 36. Based on these considerations, $\alpha$-diazo$\beta$-keto nitrile 35d was prepared. In the event, exposure of 35d to $10 \mathrm{~mol} \%$ of $\mathrm{Cu}(\mathrm{hfacac})_{2}$ provided norcaradiene 36d in good yield. Notably, $\alpha$-diazo- $\beta$-keto nitriles require high temperatures to undergo dediazotization with copper catalysts; in the case of $\mathbf{3 5 d} \rightarrow \mathbf{3 6} \mathbf{d}$, the best yields were observed when heated for short periods to $120^{\circ} \mathrm{C}$ using microwave irradiation. Nonetheless, norcaradiene 36d represents the first example of a fully substituted cyclopropane that is formed through an intramolecular arene cyclopropanation reaction.

Based on these promising results, a substrate bearing a pendant furan group was prepared (37, Scheme 8). ${ }^{29}$ Exposure of $\alpha$-diazo- $\beta$-keto nitrile 37 to $\mathrm{Cu}(\text { hfacac })_{2}$ in dichloromethane with heating to $120^{\circ} \mathrm{C}$ in a microwave reactor for one minute delivered norcaradiene 38 in $65 \%$
Table 2 Influence of Catalyst and Substrate on Norcaradiene Formation

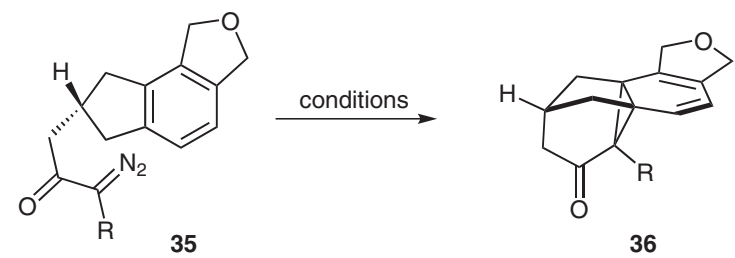

\begin{tabular}{llllll}
\hline Entry & $\mathbf{3 5}$ & $\mathrm{R}$ & $\mathrm{Catalyst}$ & Product 36 & Yield $(\%)^{\mathrm{a}}$ \\
\hline 1 & $\mathbf{3 5 a}$ & $\mathrm{H}$ & $\mathrm{Rh}_{2}(\mathrm{OAc})_{4}{ }^{\mathrm{b}}$ & $\mathbf{3 6 a}$ & 14 \\
2 & $\mathbf{3 5 a}$ & $\mathrm{H}$ & $\mathrm{Rh}_{2}(\mathrm{cap})_{4}{ }^{\mathrm{b}}$ & $\mathbf{3 6 a}$ & 1 \\
3 & $\mathbf{3 5 a}$ & $\mathrm{H}$ & $\mathrm{Rh}_{2}(\mathrm{tfa})_{4}{ }^{\mathrm{b}}$ & $\mathbf{3 6 a}$ & 5 \\
4 & $\mathbf{3 5 a}$ & $\mathrm{H}$ & $\mathrm{Cu}(\mathrm{acac})_{2}{ }^{\mathrm{c}}$ & $\mathbf{3 6 a}$ & 40 \\
5 & $\mathbf{3 5 a}$ & $\mathrm{H}$ & $\mathrm{Cu}(\text { tfacac })_{2}{ }^{\mathrm{c}}$ & $\mathbf{3 6 a}$ & $50(73)^{\mathrm{d}}$ \\
6 & $\mathbf{3 5 a}$ & $\mathrm{H}$ & $\mathrm{Cu}(\mathrm{hfacac})_{2}{ }^{\mathrm{c}}$ & $\mathbf{3 6 a}$ & 30 \\
7 & $\mathbf{3 5 a}$ & $\mathrm{H}$ & $\mathrm{Cu}(\mathrm{tmhd})_{2}{ }^{\mathrm{c}}$ & $\mathbf{3 6 a}$ & 28 \\
8 & $\mathbf{3 5 a}$ & $\mathrm{H}$ & $\mathrm{Cu}(\text { tbs })_{2}{ }^{\mathrm{c}}$ & $\mathbf{3 6 a}$ & 11 \\
9 & $\mathbf{3 5 b}$ & $\mathrm{Me}$ & $\mathrm{Cu}(\mathrm{acac})_{2}{ }^{\mathrm{c}}$ & $\mathbf{3 6 b}$ & 7 \\
10 & $\mathbf{3 5 c}$ & $\mathrm{CO}{ }_{2} \mathrm{Me}$ & $\mathrm{Cu}(\mathrm{hfacac})_{2}{ }^{\mathrm{c}}$ & $\mathbf{3 6 c}$ & 2 \\
11 & $\mathbf{3 5 d}$ & $\mathrm{CN}$ & $\mathrm{Cu}(\mathrm{hfacac})_{2}{ }^{\mathrm{c}}$ & $\mathbf{3 6 d}$ & 66
\end{tabular}

${ }^{a}$ Determined by ${ }^{1} \mathrm{H}$ NMR analysis of the crude reaction mixture, using an internal standard.

${ }^{\mathrm{b}}$ Method A: [35] $=0.01 \mathrm{M}$, [cat.] $=0.001 \mathrm{M}, \mathrm{CD}_{2} \mathrm{Cl}_{2}, 22{ }^{\circ} \mathrm{C}, 12 \mathrm{~h}$. ${ }^{\mathrm{c}}$ Method B: [35] $=0.01 \mathrm{M}$, [cat.] $=0.001 \mathrm{M}, \mathrm{CD}_{2} \mathrm{Cl}_{2}, 100{ }^{\circ} \mathrm{C}(\mathrm{MW})$, $1 \mathrm{~min}$.

${ }^{\mathrm{d}}$ Isolated yield, slow addition of $\mathbf{3 5}$, DCE, reflux.

yield. Norcaradiene $\mathbf{3 8}$ was advanced to salvileucalin B in five additional steps. Notably, these studies revealed that norcaradiene carboxaldehyde 39 undergoes a facile retroClaisen rearrangement to furnish a highly unstable vinyl ether product 40. Consistent with Boeckman and coworkers' findings that retro-Claisen rearrangements of vinyl cyclopropanecarboxaldehydes are typically reversible, ${ }^{30}$ exposure of vinyl ether $\mathbf{4 0}$ to DIBAL-H at $-40{ }^{\circ} \mathrm{C}$ delivered primary alcohol $\mathbf{4 1}$, the result of kinetic reductive trapping of putative aldehyde 39. Subsequent Pd-catalyzed carbonylative cyclization and chemoselective allylic oxidation provided the natural product. ${ }^{31}$

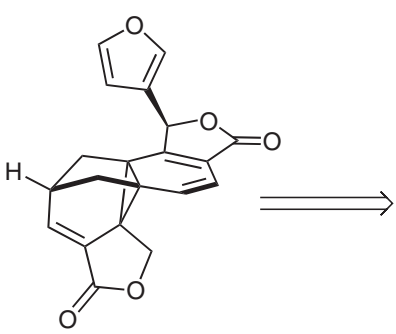

salvileucalin B (32)
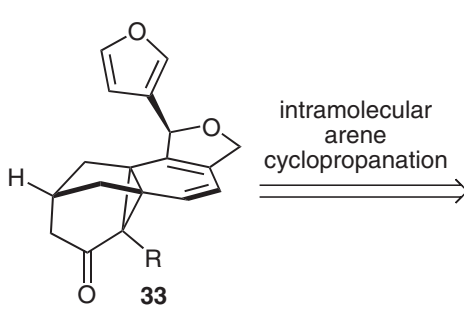

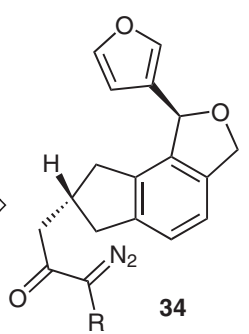

34

Scheme 7 Retrosynthetic analysis for salvileucalin B (32) 

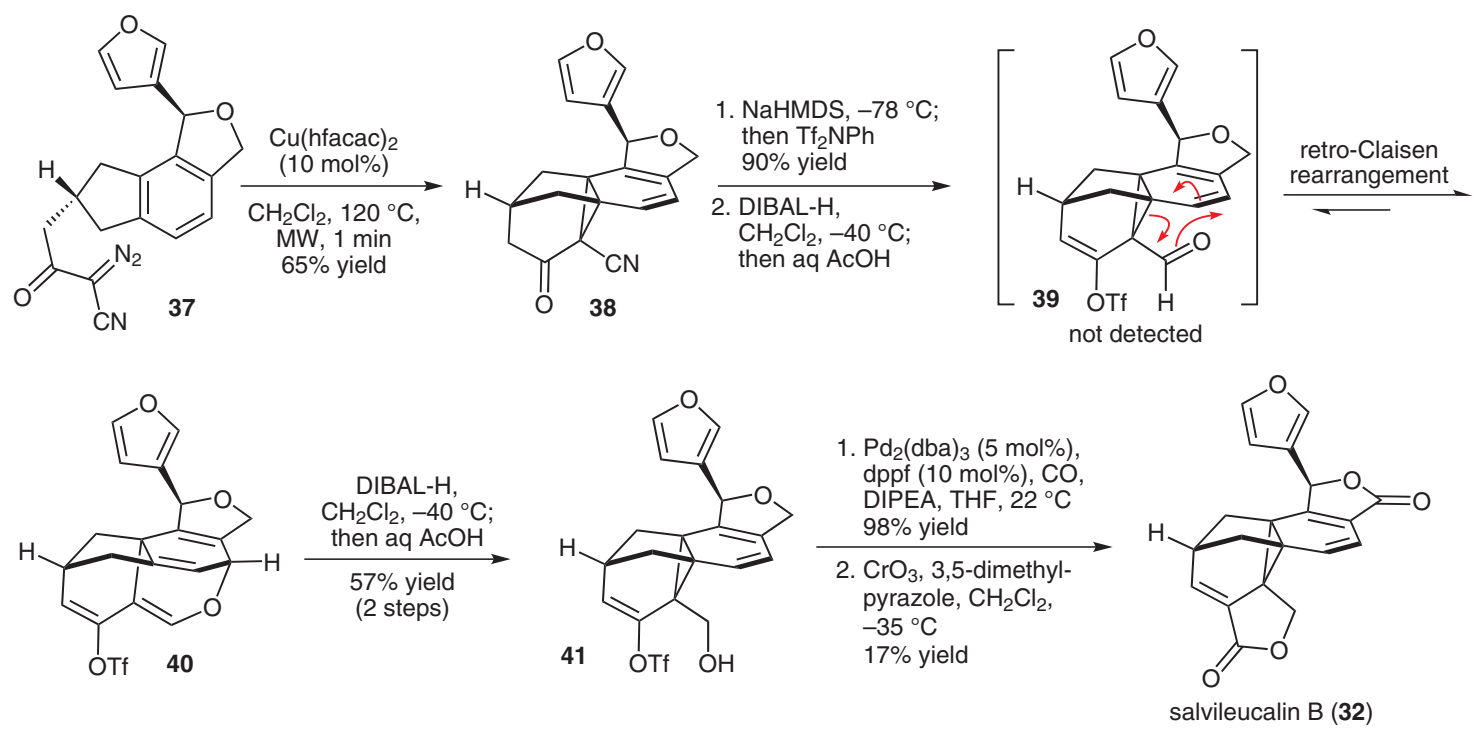

Scheme 8 Reisman and co-workers' synthesis of salvileucalin $\mathrm{B}^{29}$

As highlighted in this Account, the intramolecular Buchner reaction has proven to be a useful transformation in the context of natural product total synthesis. Although these synthetic endeavors have driven methodological advances in arene cyclopropanation, there are still several challenges that remain. In particular, despite tremendous advances in the catalytic asymmetric cyclopropanation of alkenes, the corresponding enantioselective arene cyclopropanations remain narrow in scope and modest in selectivity. ${ }^{32} \mathrm{We}$ anticipate that the Buchner reaction will continue to find application in synthesis and inspire innovation in methods development for years to come.

\section{Acknowledgment}

Financial support from the California Institute of Technology is gratefully acknowledged.

\section{References and Notes}

(1) (a) Buchner, E.; Curtius, T. Ber. Dtsch. Chem. Ges. 1885, 2377. (b) Buchner, E. Ber. Dtsch. Chem. Ges. 1896, 106.

(2) Doering, W. V. E.; Laber, G.; Vonderwahl, R.; Chamberlain, N. F.; Williams, R. B. J. Am. Chem. Soc. 1956, 78, 5448.

(3) Two other groups also proposed that the Buchner reaction provides cycloheptatriene products; however, Doering's report ${ }^{2}$ was the first to confirm this assignment by ${ }^{1} \mathrm{H}$ NMR. See: (a) DeJong, A. W. K. Recl. Trav. Chim. 1937, 198. (b) Grundmann, C.; Ottmann, G. Justus Liebigs Ann. Chem 1953, 163.

(4) Reviews: (a) Maier, G. Angew. Chem., Int. Ed. Engl. 1967, 6, 402. (b) McNamara, O. A.; Maguire, A. R. Tetrahedron 2011, 67, 9 .

(5) First direct observation of bicyclo[4.1.0]hepta-2,4-diene: Rubin, M. B. J. Am. Chem. Soc. 1981, 103, 7791.

(6) Wehner, R.; Guenther, H. J. Am. Chem. Soc. 1975, 97, 923.

(7) For an early example see: Ciganek, E. J. Am. Chem. Soc. 1967, 89, 1454.

(8) For early examples, see: (a) Prinzbach, H.; Fischer, U.; Cruse, R. Angew. Chem., Int. Ed. Engl. 1966, 5, 251.

(b) Ganter, C.; Roberts, J. D. J. Am. Chem. Soc. 1966, 88, 741.
(9) (a) Vogel, E.; Roth, H. D.; Wiedeman, W.; Gunther, H.; Eimer, J. Justus Liebigs Ann. Chem. 1972, 1. (b) Roth, W. R.; Klarner, F. G.; Siepert, G.; Lennartz, H. W. Chem. Ber. 1992, 125, 217.

(10) (a) Pommer, H. Angew. Chem. 1950, 62, 281. (b) BartelsKeith, J. R.; Johnson, A. W.; Taylor, W. I. J. Chem. Soc. 1951, 2352.

(11) (a) Scott, L. T. Chem. Commun. 1973, 22, 882. (b) Scott, L. T.; Minton, M. A.; Kirms, M. A. J. Am. Chem. Soc. 1980, $102,6311$.

(12) (a) Anciaux, A. J.; Demonceau, A.; Hubert, A. J.; Noels, A. F.; Petiniot, N.; Teyssie, P. Chem. Commun. 1980, 16, 765. (b) Anciaux, A. J.; Demonceau, A.; Noels, A. F.; Hubert, A. J.; Warin, R.; Teyssie, P. J. Org. Chem. 1981, 46, 873.

(13) Copper and rhodium are the most commonly employed catalysts, however, silver and iron catalysts have also been reported. Silver: (a) Lovely, C. J.; Browning, R. G.; Badarinarayana, V.; Dias, H. V. R. Tetrahedron Lett. 2005, 46, 2453. Iron: (b) Mbuvi, H. M.; Woo, L. K. J. Porphyrins Phthalocyanines 2009, 13, 136.

(14) Reviews: (a) Doyle, M. P.; McKervey, M. A.; Ye, T. Modern Catalytic Methods for Organic Synthesis with Diazo Compounds; John Wiley and Sons: New York, 1998, 298.

(b) Ye, T.; Mckervey, M. A. Chem. Rev. 1994, 94, 1091.

(c) Merlic, C. A.; Zechman, A. L. Synthesis 2003, 1137.

(d) Foley, D. A.; Maguire, A. R. Tetrahedron 2011, 67, 1131.

(15) (a) McKervey, M. A.; Tuladhar, S. M.; Twohig, M. F. Chem. Commun. 1984, 2, 129. (b) Kennedy, M.; McKervey, M. A.; Maguire, A. R.; Tuladhar, S. M.; Twohig, M. F. J. Chem. Soc., Perkin Trans. 1 1990, 4, 1047. (c) Maguire, A. R.; O'Leary, P.; Harrington, F.; Lawrence, S. E.; Blake, A. J. J. Org. Chem. 2001, 66, 7166.

(16) (a) Pusino, A.; Saba, A.; Rosnati, V. Tetrahedron 1986, 42, 4319. (b) Doyle, M. P.; Shanklin, M. S.; Pho, H. Q. Tetrahedron Lett. 1988, 29, 2639. (c) Moody, C. J.; Miah, S.; Slawin, A. M. Z.; Mansfield, D. J.; Richards, I. C. J. Chem. Soc., Perkin Trans. 1 1998, 24, 4067.

(17) Padwa, A.; Austin, D. J.; Price, A. T.; Semones, M. A.; Doyle, M. P.; Protopopova, M. N.; Winchester, W. R.; Tran, A. J. Am. Chem. Soc. 1993, 115, 8669.

(18) (a) Wee, A. G. H.; Liu, B.; Zhang, L. J. Org. Chem. 1992, 57, 4404. (b) Padwa, A.; Austin, D. J.; Price, A. T.; Semones, M. A.; Doyle, M. P.; Protopopova, M. N.; 
Winchester, W. R.; Tran, A. J. Am. Chem. Soc. 1993, 115, 8669.

(19) Kennedy, M.; McKervey, M. A. J. Chem. Soc., Perkin Trans. 1 1991, 10, 2565.

(20) (a) Frey, B.; Wells, A. P.; Rogers, D. H.; Mander, L. N. J. Am. Chem. Soc. 1998, 120, 1914. (b) Frey, B.; Wells, A. P.; Roden, F.; Au, T. D.; Hockless, D. C.; Willis, A. C.; Mander, L. N. Aust. J. Chem. 2000, 53, 819.

(21) Manderand colleagues subsequently reported an alternative approach to the related natural product harringtonolide: Zhang, H.; Appels, D. C.; Hockless, D. D. R.; Mander, L. N. Tetrahedron Lett. 1998, 39, 6577.

(22) Taber, D. F.; Ruckle, R. E. J. Am. Chem. Soc. 1986, 108, 7686.

(23) (a) Rogers, D. H.; Morris, J. C.; Roden, F. S.; Frey, B.; King, G. R.; Russkamp, F.-W.; Bell, R. A.; Mander, L. N. Pure Appl. Chem. 1996, 68, 515. (b) Morris, J. C.; Mander, L. N.; Hockless, D. C. R. Synthesis 1998, 455.

(24) King, G. R.; Mander, L. N.; Monck, N. J. T.; Morris, J. C.; Zhang, H. B. J. Am. Chem. Soc. 1997, 119, 3828.

(25) Aoyagi, Y.; Yamazaki, A.; Nakatsugawa, C.; Fukaya, H.; Takeya, K.; Kawauchi, S.; Izumi, H. Org. Lett. 2008, 10, 4429.

(26) Levin, S.; Nani, R. R.; Reisman, S. E. Org. Lett. 2010, 12, 780.

(27) Cyclopentanones $\mathbf{i}$ and ii were determined to be the major byproducts (Figure 2).
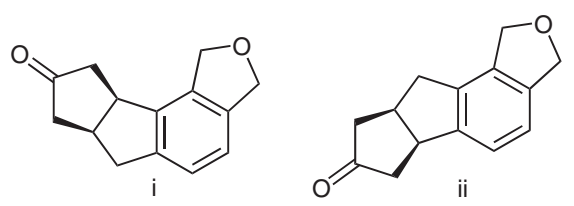

Figure 2
(28) Substrates $\mathbf{3 5} \mathbf{b}$ and $\mathbf{3 5} \mathbf{c}$ were screened against an array of rhodium and copper catalysts; Table 1, entries 9 and 10 represent the best catalysts identified for the formation of 36b and 36c, respectively.

(29) Levin, S. L.; Nani, R. R.; Reisman, S. E. J. Am. Chem. Soc. 2011, 133, 774.

(30) (a) Boeckman, R. K.; Flann, C. J.; Poss, K. M. J. Am. Chem. Soc. 1985, 107, 4359. (b) Boeckman, R. K.; Shair, M. D.; Vargas, J. R.; Stolz, L. A. J. Org. Chem. 1993, 58, 1295. (c) Boeckman, R. K.; Reeder, M. R. J. Org. Chem. 1997, 62, 6456. (d) Boeckman, R. K.; Zhang, J.; Reeder, M. R. Org. Lett. 2002, 4, 3891.

(31) Ketoaldehyde iii (Figure 3 ) is also formed in $36 \%$ yield; iii can be converted into 32 using catalytic $\mathrm{Rh}(\operatorname{cod}) \mathrm{Cl}_{2}$ and diphenylphosphinopropane. See: Phan D. H. T., Kim B., Dong V. M.; J. Am. Chem. Soc.; 2009, 131: 156

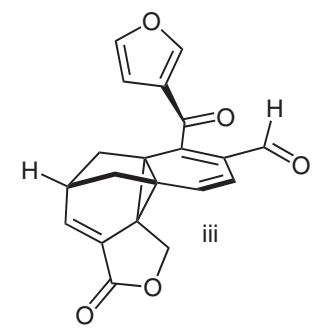

Figure 3

(32) (a) Doyle, M. P.; Ene, D. G.; Forbes, D. C.; Pillow, T. H. Chem. Commun. 1999, 17, 1691. (b) O'Keeffe, S.; Harrington, F.; Maguire, A. R. Synlett 2007, 2367. (c) O’Neill, S.; O'Keeffe, S.; Harrington, F.; Maguire, A. R. Synlett 2009, 2312. 